\title{
Celoživotní učení pro rozvoj znalostí a kompetencí obyvatel zohledňující podmínky pro místní udržitelný rozvoj
}

\author{
Jana Dlouhá, Zuzana Dvořáková Líšková, Veronika Ježková
}

Envigogika 16 (2) - Inspirace /Inspiration

Published/ Publikováno 30. 12. 2021

DOI: http://doi.org/10.14712/18023061.635

\begin{abstract}
Abstrakt
Článek rekapituluje teoretická východiska andragogiky a pokouší se je uvést do kontextu celoživotního učení, které by podpořilo aktéry udržitelného rozvoje na místní úrovni - zprostředkovalo by jim znalosti a dovednosti potřebné $\mathrm{k}$ tomu, aby mohli reagovat na stoupající požadavky rychle se měnícího světa. Takto zaměřené programy mohou vycházet z konceptu místně zakotveného učení, sociálního učení a/nebo transformatinvího učení a nabývat různých forem. Autoři také diskutují strategické dokumenty celoživotního učení na evropské úrovni i v rámci ČR a uvádějí př́ílad inovativní metody založené na foresightu.
\end{abstract}

\section{Klíčová slova}

Andragogika; celoživotní učení; udržitelný rozvoj; pedagogické metody.

\begin{abstract}
The text of this article provides a brief overview of the theoretical foundations of andragogy in the context of lifelong learning that would support actors of sustainable development at the local level - providing them with the knowledge and skills needed to respond to the increasing demands of a rapidly changing world. Lifelong learning programmes based on the outlined principles can be considered within the concepts of place-based learning, social learning and/or transformative learning and take different forms. The authors also discuss strategic documents that concern lifelong learning at European level and within the Czech Republic, and give an example of an innovative foresight-based method.
\end{abstract}

\section{Key words}

Andragogy; lifelong learning; sustainable development; pedagogical methods. 


\section{Hlavní východiska a metodické přístupy}

Vymezení pojmu celoživotní učení (CŽU) je součástí dokumentu Strategie celoživotního učení ČR 2007-2015 (MŠMT, 2007). Zde jej chápeme v širším smyslu, jako "další vzdělávání, [které] probíhá po dosaženi určitého stupně vzdělání, resp. po prvním vstupu vzdělávajícího se na trh práce." (ibid.), což více odpovídá anglickému ekvivalentu "lifelong learning".

Model celoživotního učení pro potřeby regionů by měl vycházet z konceptu "učícího se regionu", který je základem metodických př́stupů pro spolupráci a komunitní vzdělávání na regionální a místní úrovni - kombinuje učení a regionální rozvoj. V učících se regionech jsou využity znalosti k neustálému zlepšování - na znalostech jako zdroji inovací je založena místní produkce, správa, i společenský život. Zde mohou hrát zásadní roli univerzity, které mají potenciál ovlivňovat udržitelný regionální rozvoj navazováním partnerství s regionálními a místními komunitami či aktéry. Se změnou vnímání role VŠ v tomto smyslu počítají v rámci Evropské unie četné politiky, např. Lisabonská agenda, Göteborská strategie a strategie Evropa 2020, jejichž cílem je inteligentní, udržitelný a inkluzivní růst. Univerzity si však musí vybudovat kapacity, aby navázaly spolupráci s místními aktéry. ${ }^{1}$ Níže jsou popsána východiska pro vytváření strategií a programů celoživotního učení.

\section{Teoretická východiska vycházející z andragogiky a dalších pedagogic- kých príístupů}

Model celoživotního učení zaměřený na rozvoj kompetencí k řešení místních problémů, a to s využitím odborného know-how (zapojení expertů) i dalších dovedností (digitální gramotnost) jako předpokladu učení, by měl vycházet $z$ těchto principů:

- využití současných poznatků o kompetencích ve vzdělávání dospělých, s ohledem na kompetence pro udržitelný rozvoj, rozpracování těchto konceptů pro oblast vzdělávání dospělých, jejich propojení s a dalšími teoriemi

- modifikace teorií sociálního učení pro oblast CŽU tak, aby výsledkem jejich uplatnění byl rozvoj kompetencí pro komunikaci, vzájemnou interakci a spolupráci mezi aktéry $\checkmark$ místě

- aplikace teorií a přístupů místně zakotveného učení pro cílovou skupinu dospělých

- teorie jsou aplikovány $s$ ohledem na relevanci témat a obsahů učení (které v projektu budeme poskytovat/sdílet s místními aktéry), a jejich rozpracování vzhledem k místním zdrojům (jak informačním, tak i těm, které podmiňují místní rozvoj)

- teorie uplatněné $v$ andragogice obecně - využití principů učení/vzdělávání dospělých (s důrazem na rozdíl od vzdělávání dětí)

- zvláštní pozornost má být věnována teorii transformativního učení, které vzniklo pro vzdělávání dospělých a jeho cílem je podchytit či podpořit společenské změny prostřednictvím vzdělání

\section{Andragogika}

Teorie učení aplikovaná v procesech regionálního rozvoje zohledňuje interakce dotčených aktérů, kteří se $v$ učení vzájemně podporují. Podmínkou je zapojení těch, kdo se učí, do kritického posuzování aktivit, cílů a představ o procesech rozvoje, i do reflexe samotného učení (Meyer et al.,

\footnotetext{
${ }^{1}$ Znalostně založený regionální rozvoj vyžaduje čtyři typy kapacit vysokých škol pro podporu tohoto rozvoje: (1) v oblasti mezioborového výzkumu zaměřeného na regionální analýzy (2) absorpční kapacita - schopnost vysokých škol podporovat místní firmy při využíaání znalostí a stimulovat regionální poptávku prostřednictvím vzdělávacích aktivit (3) kapacita spolupráce řadí vysoké školy mezi nezávislé regionální aktéry, schopné pracovat "přes akademické hranice" (4) role "leadera" dovoluje univerzitám prosazovat regionální vize a navrhovat společné aktivity s regionálními aktéry. Díky všem těmto kapacitám se mění role univerzit na důležitého aktéra regionálního rozvoje (Meyer et al., 2018).
} 
2018). Pro design modelu celoživotního učení pro potřeby rozvoje regionů mohou být využity poznatky andragogiky, zvláště teorie rozpracované Malcolmem Knowlesem (1984), který vidí rozdíl mezi pedagogikou a andragogikou $v$ tom, že dospělý jedinec je (na rozdíl od dítěte):

- nezávislou osobností

- může využít svých zkušeností jako zdroje pro učení

- jeho schopnost učit se souvisí s naplňováním jeho sociálních rolí

- zájem o učení se přesouvá z předmětu učení k řešení problému z praxe (a potřebě relevantních znalostí)

- motivace učit se je vnitřní (Knowles 1984: 12).

Z těchto poznatků Knowles odvodil 4 principy andragogiky, které se vztahují ke vzdělávání dospělých:

- dospělí musí být zapojeni do plánování a hodnocení svého učení

- zkušenosti (včetně chyb) poskytují základ pro vzdělávací aktivity

- dospělí se nejvíce zajímají o předměty, které mají okamžitý význam a dopad na jejich práci nebo osobní život

- učení dospělých je zaměřeno spíše na řešení problémů než učení se obsahu (Kearsley, 2010).

Vzdělávací aktivity $v$ rámci celoživotního učení je tedy vždy nutné realizovat tak, aby $v$ co nejvyšší míře reflektovaly konkrétní životní situace, resp. řešení konkrétních životních otázek, a zohledňovaly předchozí znalosti a dovednosti účastníka celoživotního vzdělávání. Dospělí se nejefektivněji učí za podmínky, že je pro ně toto vzdělávání smysluplné (at' už z ekonomických, společenských či osobních důvodů) a mají možnost využití široké nabídky různých zdrojů. Zároveň je nutné zde uplatňovat zásady individuálního př́stupu, motivace účastníka celoživotního učení, orientace na jeho zájmy a hodnoty a využívání přímé zkušenosti při vzdělávání. Existuje řada bariér z pohledu účastníka vzdělávacího procesu, a proto je nutné využít takové přístupy, aby jednotlivé bariéry byly $v$ co největší míře odstraněny. To s sebou nese nutnost posílení osobní motivace účastníků, kterou zajistí např. to, že výstupy mají př́mou souvislost s aktuálním zaměstnáním, zvyšují možnost nalezení nového uplatnění a/nebo přispívají k řešení problémů v jeho/jejím životě či blízkém společenství.

Z výše uvedeného Ize odvodit výukové metody vhodné pro celoživotní učení. V dalším textu se budeme zabývat koncepty relevantními pro udržitelný rozvoj: rozvíjení klíčových kompetencí UR, místně zakotvené učení, a sociální a transformativní učení. Obecně je možné využít:

- dovednostně-praktické metody,

- heuristické metody (řešení problémů),

- metody situační a inscenační,

- simulace a hry,

- skupinové učení,

- individualizovaná výuka,

- projektová výuka,

- brainstorming a brainwriting,

- sugestopedie a superlearning,

- diskuze a vzájemné sdílení znalostí a zkušeností. 
Využití jednotlivých metod se samozřejmě liší dle charakteru konkrétní vzdělávací aktivity, eventuálně volby cílové skupiny (vzdělávaného dospělého). Metody se mohou vzájemně prolínat a kombinovat, doplněny mohou být i metodami klasickými (přednáška, demonstrace, napodobování apod.), měly by však vždy respektovat požadavky a možnosti účastníka celoživotního učení.

Nutno ještě podotknout, že metody a formy vzdělávání dospělých se v průběhu času mění, dalo by se říci, že podléhají určitým módním trendům. $V$ pojetí andragogiky, jakožto relativně mladého vědního oboru, představují metody i formy vzdělávání dospělých stále se proměňující dynamickou "směs", která reflektuje trendy, měnící se požadavky vzdělávaných, zkušenosti lektorů a vzdělávacích institucí i zahraniční vlivy. Mezi nejčastější formy v rámci celoživotního vzdělávání dospělých patří kurz, workshop, outdoorový trénink, aktivity v rámci adventure education, koučink, development centra apod.

Některé formy mohou podporovat digitální gramotnost: významným podpůrným prostředkem v celoživotním vzdělávání je například také e-learning, který Ize využívat v prezenční, distanční a kombinované formě výuky. Jak již bylo zmíněno výše, využití e-learningu s sebou nese určité nároky na znalosti a dovednosti vzdělávaného, jeho technické vybavení, jakož i nároky na autora obsahu konkrétní vzdělávací aktivity ve smyslu schopnosti zpracování dané problematiky e-learningovou formou. Vysoce atraktivní je využívání virtuální reality, která přináší vzdělávanému zcela unikátní a hluboce emotivní prožitek z učení. Tím dochází ke zvyšování efektivity celého vzdělávacího procesu.

\section{Pedagogické koncepty ze vzdělávání dospělých pro udržitelný rozvoj}

Vzdělávání pro udržitelný rozvoj (VUR) má výrazně transformativní povahu; na úrovni expertů i mezinárodních organizací se vedou intenzivní diskuse o podobě tohoto vzdělávání (UNESCO, 2017). Mělo by především rozvíjet kompetence k předjímání (udržitelné) budoucnosti a schopnosti realizovat tyto vize a plány. Relevantní koncepty se liší podle toho, zda jsou využitelné obecně (ty, které jako vzdělávací cíle stanovují kompetence ve VUR); vycházejí z místního kontextu (místně zakotvené učení); nebo počítají s interakcí mezi různorodými aktéry (sociální učení). Tyto koncepty nebo jejich části by měly být analyzovány z hlediska možného přizpůsobení pro potřeby vzdělávání dospělých.

\section{Vzdělávací cíle v okruhu udržitelnosti}

Po obsahové stránce jsou pro model CŽU relevantní témata ekonomická, sociální (z hlediska role kultury $v$ rozvoji), a environmentální - v podobě, která usnadní naplňování strategií a cílů udržitelného rozvoje (vyjádřených ve strategických dokumentech různých úrovní), a to v kontextu místa/regionu. Tuto obsahovou stránku materiálů pro CŽU pokrývají stávající zdroje informací zajištúuící přenos poznatků $z$ vědy do praxe. ${ }^{2}$

Vzdělávacími cíli nejsou ovšem jen znalosti - v akademické debatě se hovoří o kompetencích jako o důležitých vzdělávacích cílech, a to na všech stupních vzdělávacího systému - tyto cíle je třeba rozšírit i pro oblast celoživotního učení. Kompetence jsou totiž nezbytné pro řešení konkrétních otázek udržitelnosti na systémové úrovni ( $v$ sociální sféře a při tvorbě politik), pomáhají uplatňovat odborné znalosti týkající se udržitelnosti v praxi, zároveň také motivují k aktivnímu občanství, jsou také základem schopnosti se kriticky se zapojit do kolektivního procesu vytváření udržitelné budoucnosti (Dlouhá et al. 2020). V českých podmínkách je prosazuje dokument Strategický rámec ČR 2030, jeho cíl 1.4 pro vzdělávání, který nabízí transformativní vizi vzdělávání, jež: „...rozvijí individuální potenciál jedinců a jejich schopnost zvládat i ovlivňovat změny a podporuje soudržnou společnost orientovanou na udržitelný rozvoj" (ÚV ČR, 2017). Základní kompetence udržitelnosti

2 V tomto smyslu může sloužit znalostní báze Enviwiki, například Portál místního udržitelného rozvoje. 
vymezilo UNESCO (2017)3; analýza relevance těchto kompetencí pro vzdělávání dospělých však chybí. Úvahy o jejich uplatnění v kontextu European skills agenda a zde vyjádřeného požadavku na rozvíjení "transformačních" dovedností v oblasti přechodu na Evropskou zelenou dohodu (European Green Deal) viz dále.

\section{Místně zakotvené učení ve vzdělávání dospělých}

Místně zakotvené učení (MZU) pracuje se znalostmi a zkušenostmi v místním kontextu, např́klad při hledání udržitelných řešení nebo pokusech o snižování nerovností plynoucích z globalizačních procesů (Smith a Sobel, 2014). Koncept MZU je běžně používaný v pedagogice a své místo má i $v$ andragogice. Jeho uplatnění vyžaduje aktivaci a/nebo využití místních znalostí, např. v programech muzea, které mapuje místní historii a kulturu; vzdělávací programy pro různé věkové skupiny z místních znalostí čerpají a současně je mohou spoluvytvářet. Konkrétní cíle vzdělávání založeného na místě, upravené pro potřeby regionu, jsou zde formulovány následovně:

- přispívat k udržitelným řešením - být aktivní, zapojovat se do místního dění;

- pracovat s místními znalostmi a zainteresovanými stranami, zkoumat rozličné pohledy a vyjasňovat si své hodnoty;

- pěstovat myšlení zaměřené na budoucnost - učení tak má podporovat tvorbu vizí a scénářů;

- procvičovat sociální učení v rámci reálných nebo simulovaných interakcí.

Tento koncept je $v$ centru pozornosti především projektové výuky, která má zprostředkovat kontakt s místním prostředím, umožnit zapojení do občanských aktivit; přináší také možnost uplatnit poznatky, angažovat se při „strategickém" plánování budoucnosti a učit se vyjednávat o její konkrétní podobě s různými společenskými skupinami. Přispívá ke stanovení konkrétních a přitom společensky př́nosných cílů, s nimiž se cílové skupiny mohou identifikovat. Zkušenosti a poznatky týkající se možností učení zaměřeného na regionální problematiku ve vzdělávání studentů byly shromážděny v certifikované metodice (Dlouhá, Dlouhý, Kapitulčinová, 2016); poznatky a zkušenosti MZU relevantní pro vzdělávání dospělých viz Stejskalová (2021).

\section{Sociální učení v místním kontextu}

Koncept sociálního učení bere na vědomí, že každý učební proces má také sociální dimenzi a je výrazně ovlivněn sociálními interakcemi účastníků a sociálním prostředím (Wals, 2007). Termín je také používán k charakterizaci určitých procesů, kde se skupiny jako celek učí od sebe navzájem.

${ }^{3}$ Z osmi základních kompetencí udržitelnosti je pro celoživotní učení nejvíce relevantní následujících 5 kompetencí:

Anticipační kompetence: schopnosti předjímat budoucnost, zhodnotit více jejích alternativ - možné, pravděpodobné a žádoucí; vytvořit vlastní vize do budoucna; uplatňovat zásadu předběžné opatrnosti; posoudit důsledky akcí, rizik a změn.

Normativní kompetence: schopnosti porozumět normám a hodnotám, které jsou základem lidského jednání; dovednost vyjednat hodnoty, zásady a dlouhodobé i krátkodobé cíle udržitelnosti; a to v kontextu střetu zájmů a kompromisů, nejistých znalostí a rozporů.

Strategická kompetence: schopnosti kolektivně rozvíjet a zavádět inovativní akce, které dále podporují udržitelnost na místní úrovni i na úrovních dalších.

Kompetence spolupráce: schopnosti učit se od ostatních; porozumět a respektovat potřeby, perspektivy a jednání druhých (empatie); chápat, rozvíjet vztahy k druhým a být k nim citliví (empatické vedení); řešit konflikty ve skupině; a podporovat spolupráci a participativní řešení problémů.

Kompetence kritického myšlení: schopnosti zpochybňovat normy, postupy a názory; reflektovat vlastní hodnoty, vnímání a činy; a zaujmout stanovisko v diskurzu udržitelnosti. 
Sociální učení má proto poměrně široký transformační dopad a mnozí autoři poukazují na to, že na tomto typu učení závisí pokrok směrem k udržitelnosti (UNECE, 2016). Proces sociálního učení se v praxi spojuje s takovou správou věcí veřejných, jež zohledňuje zpětnou vazbu od rozmanitých aktérů a vyžaduje polycentrickou tvorbu politik (Bagheri, Hjorth, 2007). Toto pojetí se rovněž uplatňuje tam, kde je důležitá role zájmových skupin, politických stran a dalších hráčủ mimo státní moc (Hall, 1993). V tomto pohledu mají veškeré procesy vyjednávání rozměr učení - aby se aktéři dokázali dohodnout na výsledku, je zde nutná určitá angažovanost a vzájemná důvěra, což pak může vést k přehodnocení původního př́stupu nebo strategie - tedy transformaci (Sol, Beers, Wals, 2013). Sociální učení vychází z reálné situace a je založeno na vztazích, $v$ jejichž rámci se lidé setkávají, naslouchají si, učí se jeden od druhého a mohou kriticky uvažovat o svých původních předpokladech a názorech. Jeho důsledkem je vzájemné obohacování a celkově prohlubování znalostí o místních problémech. ${ }^{4}$

V rámci sociálních interakcí s dalšími jedinci či skupinami, které jsou definičním znakem sociálního učení, se podporují sociální kompetence, jako jsou dovednosti vyjednávat, dosáhnout společného řešení nebo přizpůsobit se stávajícím okolnostem a přijmout či zohlednit kontext, $v$ němž jsou realizovány plánované aktivity. $V$ definici sociálního učení byly jako nejdůležitější znaky identifikovány čtyři prvky procesu učení (Wals, 2007):

- Komunikace: předpoklad sociálního učení, v němž se rozvíjí sdílené porozumění, a tudíž i podmínky pro následné akce. Komunikace může nastat přímou interakcí, při konverzaci, nebo prostřednictvím médií.

- Spolupráce: kooperativní struktury, jako jsou "komunity praxe" nebo "sítě sociálních aktérü", jsou klíčovými pojmy v konceptu sociálního učení.

- Akce: sociální aktéři nebo jednotlivci jsou připraveni zaujmout postoj a v dané situaci aktivně jednat (účastníci učení se proto považují za kompetentní aktéry)

- Reflexe: aktéři by měli být schopni zhodnotit zkušenost z učení, vyvodit z ní závěry a promítnout ji do změny svého chování.

Koncepce sociálního učení nejen odráží a podporuje schopnost jednotlivce jednat v prostredí podle svých vlastních norem a zvyků, ale také odráží společenské zvyklosti vyjednávat a sdílet poznatky (Cobb, Bowers, 1999). Termín je také používán k charakterizaci určitých procesů, kde se skupiny jako celek učí, probíhají tedy na úrovni vzdělávací organizace nebo uvnitř učící se společnosti. Sociální učení má proto poměrně široký transformační dopad a mnozí autoři poukazují na to, že na tomto typu učení závisí pokrok směrem k udržitelnosti (UNECE, 2016).

\section{Transformativní učení pro podporu místního rozvoje}

Pro udržitelný rozvoj jsou nezbytné procesy tzv. sociálního učení, které jsou předpokladem společného řešení problémů (ve spolupráci aktérů) a jež mají navíc určitý transformativní potenciál. Vhodně vedený proces sociálního učení tak může vyústit $v$ žádoucí změny, například při plánování a realizaci určitých aktivit $v$ místě. Tuto jeho transformativní dimenzi je možné reflektovat (a následně podporovat) s využitím konceptu transformativního učení, jenž byl vyvinut právě pro vzdělávání dospělých. Hlavními principy transformativního učení jsou jednak kritická reflexe předpokladů stávající perspektivy (problém) a následný kritický výběr nejlepšího úsudku pro transformaci této perspektivy v nový prístup přinášející řešení (Mezirow, 2006). Model perspektivní transformace byl

\footnotetext{
${ }^{4}$ Sociální učení Ize rozpoznat, diskutovat a analyzovat pomocí indikátorů - jsou součástí velmi rozmanitých procesů komunikace (Dlouhá, Dlouhý, Kapitulčinová, 2016). Tomuto konceptu bylo věnováno zvláštní číslo Envigogiky "Sociální učení v regionálních procesech udržitelného rozvoje" (Envigogika, Vol 10 No 1 (2015)).
} 
popsán jako sled fází, jejichž výsledkem je nové utváření vztahů mezi jednotlivci či aktéry. ${ }^{5}$ Vzdělávacím cílem tohoto typu učení pak je rozvoj kompetencí pro naplnění těchto nových rolí jednotlivců nebo skupin v nově vytvořené situaci (viz též Dlouhá et al., 2021a, b).

\section{Forma CŽU}

Obecně se celoživotní učení může odehrávat ve formální, neformální a informální rovině. Formální podoba je spíše pokračujícím vzděláváním a často (neprávem) přebírá charakteristiky vzdělávání na nižších stupních. Neformální vzdělávání naproti tomu využívá různé přiležitosti, které nejsou vytrženy z občanského či profesního života, dochází však při nich k učení; informální učení se pak děje přirozeně, neplánovaně při každodenních aktivitách (Van Merriënboer et al., 2009). Formální vzdělávání vyžaduje institucionální zázemí, které ovšem v ČR chybí; možnosti neformálního učení je ale možné systematicky rozšiřovat, kdežto informální probíhá spontánně a Ize jej podporovat pouze zprostředkovaně.

Z hlediska formy, která by měla být zvolena pro realizaci aktivit CžU, je třeba zkoumat též genderové aspekty. Je obecně známo, že ačkoli je celoživotní učení nezbytností pro společnosti založené na znalostech, nemají k němu různé společenské skupiny stejný př́stup. Účast $v$ celoživotním učení se liší nejen mezi státy, věkovými skupinami, profesemi a úrovněmi vzdělání, ale z hlediska genderu - ženy jsou málo zastoupeny (Van Merriënboer et al., 2009). V genderové dimenzi má být využita intersekcionální perspektiva (tj. zohlednění toho, jakou roli hraje intersekce možných znevýhodnění - nejen genderu - např. s ohledem na dosažené vzdělání). Toto by pak mělo ovlivnit výběr vhodných forem CŽU, například co se týče časové dostupnosti, technické náročnosti atd.

Obecně by formální podoba aktivit CŽU měla vycházet z teorie implementace - pro využití poznatků $\vee$ praxi je důležitá motivace a zájem (ownership), které jsou ovlivněny znalostmi a hodnotami. Tento typ učení v oblasti udržitelnosti má 3 složky: 1) koncepty a hodnoty udržitelnosti, 2) metody a procesy učení, výzkumu a managementu, 3) výsledky učení, tedy vize a opatření pro místní udržitelný rozvoj (a míra jejich naplnění). Zájem (ownership) podporuje nejen nové př́stupy (inovace), ale též identifikaci těch, kdo se učí, s výsledky učení, jako základ jejich implementace (Meyer et al., 2018).

\section{Potřebnost CŽU z hlediska praxe}

Hledisko potřebnosti systému celoživotního učení (CŽU) v praxi vyjadřují strategické dokumenty, které se z různých úrovní zabývají potřebností rozvoje kompetencí občanů v produktivním věku. Koncepty celoživotního učení, které byly formulovány mezinárodními organizacemi jako Rada Evropy, UNESCO, OECD v 60. a 70. letech 20. století, sledovaly především cíle sociálního a kulturního rozvoje společnosti prostřednictvím vzdělávání přístupného všem bez jakékoliv diskriminace. $V$ tomto duchu byly formulovány i mezinárodní úmluvy a doporučení přijatá UNESCO. Na prvním místě byly sociální a kulturní cíle, zatímco cíle vztahující se k práci hrály přinejlepším druhotnou roli a environmentální cíle byly víceméně opomíjeny.

Koncept „permanentního vzdělávání" Rady Evropy (Council of Europe, 1978) zdůrazňoval především podporu rovnosti vzdělávacích príležitostí. Práce UNESCO „Learning to be" (Faure, 1972) byla

\footnotetext{
5 Změny $v$ zaběhnutých zvyklostech jsou nutným předpokladem inovací a $\mathrm{k}$ tomu je zapotřebí i určité změny myšlení. V průběhu života si člověk osvojuje určitý způsob vidění světa - tzv. významovou perspektivu, která mu slouží jako referenční rámec. Pokud ale tyto předpoklady reflektuje a vyhodnotí jako neadekvátní a neplatné (což se děje $v$ souvislosti se zrychlujícím se rozvojem $v$ mnoha oblastech), je potřeba hledat novou významovou perspektivu. $\mathrm{K}$ tomu pomáhá transformativní učení, které probíhá v několika fázích, kdy je dosavadní zkušenost po získání nových informací a podnětů přehodnocena, a na tomto základě pak začíná plánování nového způsobu jednání a jsou vytvářeny kompetence k naplnění nových rolí (Dvořáková, 2012). Mezirow (1991, 1997) považuje transformativní učení za nejvýznamnější vývojový úkol dospělosti a také za základ vzdělávání dospělých (tedy ústřední proces rozvoje $v$ dospělosti).
} 
orientována na globální vzdělávací politiku a sociokulturní poslání této organizace zejména se zřetelem $\mathrm{k}$ pozvednutí celkové vzdělanostní úrovně $v$ zemích na různém stupni společenského a ekonomického rozvoje. Koncept „periodického vzdělávání" OECD (Kallen, Bergtsson, 1973), byl veden snahou prolomit cyklus neustále se prodlužujícího a málo efektivního a nákladného počátečního vzdělávání.

Koncept celoživotního učení, s jakým pracujeme dnes, má své základy v 90. letech minulého století. Propojuje oblasti environmentální sociální a ekonomickou, preferuje realističtější cíle spojené s programy celoživotního učení zaměřenými na rozvoj lidských zdrojů, zejména ve vztahu k potřebám efektivního fungování cirkulární ekonomiky. Těžiště tohoto konceptu se přesouvá k problematice odborného vzdělávání a přípravy, k uplatnění v pracovním životě.

Ve strategických dokumentech EU je na celoživotní učení nahlíženo jak z hlediska zaměstnanosti a rozvoje lidských zdrojů, tak z hlediska vzdělávání. Základním dokumentem je Lisabonská strategie, ve které má celoživotní učení zásadní roli. Dále je odborné vzdělávání popsáno již v Kodaňské deklaraci. Př́mo v návaznosti na zasedání v Lisabonu vydala Evropská komise v říjnu 2000 Memorandum o celoživotním učení (Memorandum on Lifelong Learning, 2000). ${ }^{6}$

\section{Česká republika a evropské strategie Cžu}

Strategické dokumenty na národní úrovni mají spíše kontextový charakter, věnují se obecnějším otázkám socioekonomického rozvoje, nebo jsou naopak přímo zaměřeny na vzdělávání. Za základní pilír CŽU je v dokumentech vnímána vzdělávací soustava.

Koncepci rozvoje oblasti celoživotního učení do roku 2015 představovala Strategie celoživotního učení České republiky spolu s navazujícím implementačním plánem (MŠMT, 2007). Od roku 2015 oblast nedisponuje výhradním strategickým materiálem, přesto však z těchto východisek čerpá tvorba navazujících dokumentů a vlastní realizace vzdělávací politiky v této oblasti. Problematika celoživotního učení pak byla prostřednictvím Strategie vzdělávací politiky ČR do roku 2020 začleněna do navazujících implementačních dokumentů. ${ }^{7}$ Výzkum vhodnosti metod CžU pro místní potřeby, a to v konfrontaci se strategickými cíli CŽU relevantními pro Českou republiku, dosud nebyl proveden.

Platné dokumenty by měly reagovat na fakt, že $v$ ČR je dlouhodobě nízká participace obyvatel v dalším vzdělávání. $\vee$ roce 2018 se zapojilo do vzdělávacích aktivit v rámci celoživotního učení $8,5 \%$ dospělých, což je méně než evropský průměr, který je 11,1 \%. Nejlepších výsledků dosahují severské státy, kde se během svého dospělého života vzdělává kolem čtvrtiny obyvatel, ve Švédsku se podíl blíží dokonce třetině (Dobeš, 2019). Přitom rozvoj celoživotního učení je podporován v mnoha strategických dokumentech na evropské i národní úrovni:

1. European skills agenda reaguje na nutnost rozvoje "transformačních" dovedností v oblasti přechodu na Evropskou zelenou dohodu (European Green Deal), probíhající digitalizaci a změny ve společnosti. Evropská agenda dovedností je pětiletý plán, který má pomoci jednotlivcům a podnikům rozvíjet dovednosti v oblastech (Evropská komise, 2020):

a) posílení udržitelné konkurenceschopnosti, jak je stanoveno v Evropské zelené dohodě;

b) zajištění sociální spravedInosti, přístupu ke vzdělání, odborné prípravě a celoživotnímu učení pro všechny obyvatele v celé Evropské unii;

\footnotetext{
${ }^{6}$ Dostupné na webových stránkách EU: http://ec.europa.eu/education/policies/III/III en.html.

7 Dostupné na https://eacea.ec.europa.eu/national-policies/eurydice/content/lifelong-learning-strategy-21 cs.
} 
c) vybudování odolnosti vưči krizím na základě poznatků získaných během pandemie COVID-19.

2. V dokumentu Evropské komise "Zpráva o České republice 2019" je celoživotní učení podporováno v piliří 4. Sociálnější Evropa - provádění evropského pilíře sociálních práv, který má za cíl "Zavést komplexní strategii pro dovednosti, podporovat celoživotní učení a uznávání dovedností a podporovat adaptabilitu pracovníků na budoucí požadavky prostřednictvím rozšiřování kvalifikace/rekvalifikace, včetně státních př́slušníků třetích zemí". Dokument vychází z faktu, že účast na odborné prípravě a celoživotním učení je nízká, zejména pokud jde o skupiny nedostatečně zastoupené na trhu práce. (Evropská komise, 2019).

3. Národní dokument, který zpracovalo MPSV Iniciativa práce 4.0 uvádí, že: „schopnost celoživotního učení bude dále nabývat na důležitosti $v$ důsledku rostoucích požadavků na flexibilitu pracovní síly vyvolaných změnami $v$ charakteru práce, variabilitou a individualizací pracovních forem. Neustálá práce $v$ rámci sítí (networking) bude vyžadovat schopnost spolupracovat a orientovat se v komplexním a multikulturním prostředí. Klíčová bude schopnost celý život se učit, vyhledávat aktivně aktuální oborové informace, využívat k sebevzdělávání dostupné nové technologie, internet, sociální média, apod. Stoupat bude role kreativního př́stupu k řešení problémů, samostatnosti, seberegulace, iniciativy, odpovědnosti a etiky. Lze očekávat, že $v$ časovém horizontu 5 -ti let budou potřebné zejména dovednosti v oblasti mobilních zařízení a mobilních aplikací, cloudů, zpracování velkých dat, využívání internetu věcí a rozvoje sdílené ekonomiky. Tyto trendy jsou patrné již v současné době." $\vee$ návaznosti na tuto studii MPSV zpracovalo počátkem roku 2017 Akční plán Práce 4.o., který definuje jako druhý strategický cíl „Podporu dalšího vzdělávání” (MPSV, 2019).

4. Rozvoj kompetencí pro celoživotního učení je dále rozpracován v dokumentu Hlavní směry vzdě-

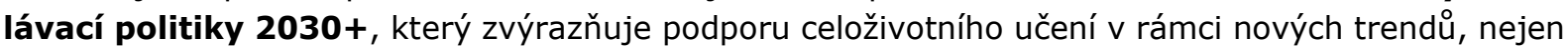
digitálních, ale souvisejících i se změnami na trhu práce, demografickými změnami (stárnutí populace), migrací a technologickou proměnou celé společnosti. Celoživotní učení je $v$ tomto dokumentu zakotveno v strategické linii: „Proměna obsahu a způsobu vzdělávaní”. V rámci celoživotního učení je cílem: „Zvyšovat motivaci dospělých k celoživotním vzdělávacím aktivitám, jejichž realizace může probíhat za podpory institucí zájmového vzdělávání (např. středisek volného času) a neformálního vzdělávání, např. typu knihovny nebo science centra." (MŠMT, 2019). Zážitkové („science centra"), pamětové (muzea, památníky) a zájmové instituce mohou nabídnout širokou škálu programů $\checkmark$ motivační formě a požadovaném obsahu.

Výzvou pro období po roce 2020 bude vznik a rozvoj komplexního a prostupného systému celoživotního učení zasazeného do evropského kontextu: „Tento systém celoživotního učení, představuje zásadní koncepční změnu pojetí vzdělávání, jeho organizačního principu, kdy všechny možnosti učení - at́ už v tradičních vzdělávacích institucích $v$ rámci vzdělávacího systému či mimo ně jsou chápány jako jediný propojený celek, který dovoluje rozmanité a četné přechody mezi vzděláváním a zaměstnáním a který umožňuje získávat stejné kvalifikace a kompetence různými cestami a kdykoli během života." (Palán, 2006, s. 25).

\section{Závěr}

Tradičně je vliv regionálních požadavků na činnost vysokých škol poměrně nízký (Lansu et al., 2012), a vztahy mezi univerzitami a místními aktéry, kterými by univerzity naplnily svou "třetí roli" ve prospěch společnosti jsou také podceněny. Citelně tak chybí zapojení odborného know-how do plánování a realizace představ budoucnosti v praxi regionálního rozvoje. 
Udržitelná budoucnost počíá se zásadním obratem v mnoha oblastech společenského života; na různých úrovních je totiž třeba reagovat na globální megatrendy ${ }^{8}$, což mění nejen mezinárodní politiky, ale i vědecké př́stupy. Nově vznikající (či již etablovaná) věda udržitelnosti, tzv. sustainability science již nemá za cíl pouze popisovat a analyzovat skutečnost, ale přispívat k předjímání budoucnosti a podloženému, tzv. evidence-based rozhodování na tomto základě (Heinrichs et al., 2016). Četné nové metody, které se $v$ tomto rámci prosazují, jsou založeny participativně: za východisko rozhodování považují nejen expertizu a hodnoty, ale berou v úvahu i společenské aktéry, kteří mají různé pohledy a zájmy. Cílem je dosáhnout nejen vědeckého, ale i společenského dopadu (impaktu). To vše by se mělo odrazit v důrazu na celoživotní učení na různých úrovních.

\section{Př́klad metody založené na předjímání budoucnosti - foresight}

Cílem aktivit CŽV je vytvářet autentické př́ležitosti k učení - jednou z možností je rozvíjet dialog o možné/žádoucí budoucnosti, kterou je $v$ silách účastníků s odbornou pomocí nejen plánovat, ale potom též vlastními silami realizovat. Předmět tohoto plánování by se stal společným tématem pro diskuze vedené interdisciplinárně a mezi různorodými aktéry, formou mezioborové komunikace.

K pochopení možných alternativ budoucnosti se dnes používají různé modely či techniky predvídání, což pomáhá vyhodnotit politické priority a určit potenciální nové směry vývoje zohledňující nové společenské požadavky a výzvy. Umožňuje to též využít vývoj v oblasti technologií a další příležitosti, ale také vzít v úvahu rizikové faktory s tím spojené. Celkem běžným nástrojem využívaným při tvorbě politiky na evropské i národních úrovních se tak stal foresight, představující soubor metod pro systematické úvahy a zkoumání možných variant budoucího vývoje, i jejich předjímání, tedy vytváření podmínek pro rozhodování (Pazour et al., 2017). Metody, které se pod tímto označením skrývají, se vyznačují zapojením aktérů, jichž se konkrétní představy budoucnosti týkají, otevřeností vưči různým alternativám, a také aktivním formováním budoucích řešení. Foresightové metody jsou ale orientované nejen na dosažení výsledku (formulace řešení či plánu), ale hlavně na participativní proces hledání těchto řešení, který posiluje připravenost na různé možnosti včetně rizikových, a podporuje vzájemné učení. $V$ něm se uplatňují multidisciplinární př́stupy (a přeshraniční dialog), utváří se dlouhodobější, do budoucnosti zaměřený pohled na určitou problematiku i její praktické aspekty.

Jak je patrné zobr. 1, metody foresightu jsou založeny na popisu stávajícího stavu, tvorbě vizí budoucnosti a plánů pro jejich naplnění, včetně realizace. Nemusí se jednat o politiky, $v$ našem př́padě lze metody použít pro plánování aktivit podporujících udržitelný rozvoj daného místa (obce, regionu) a jejich realizaci. Ve fázi analýzy se uplatní odborné poznatky a metody; ve fázích tvorby vizí

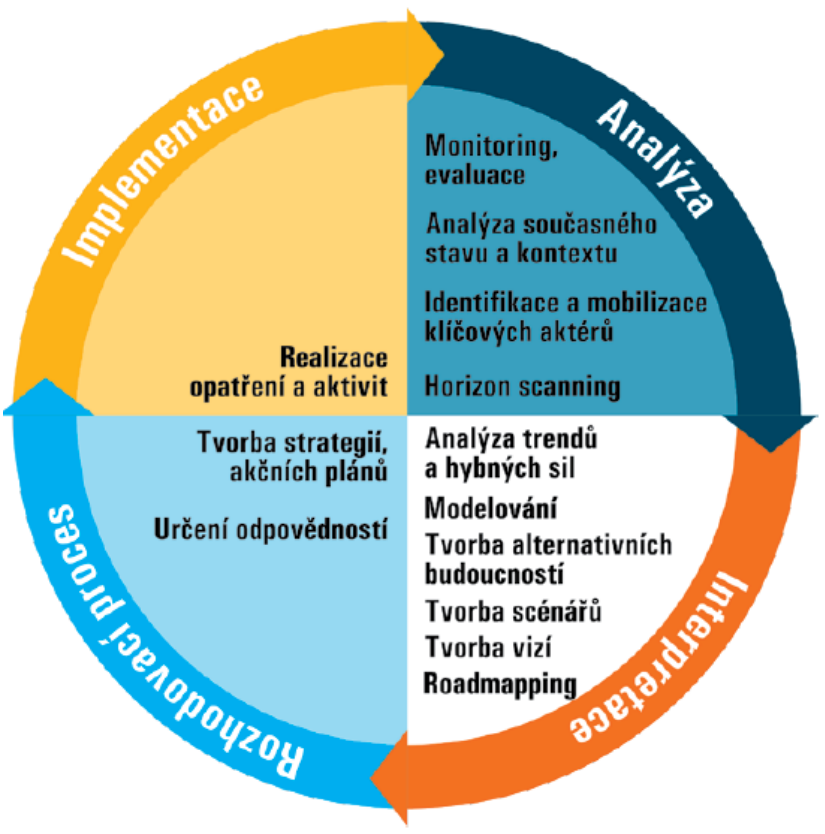

Obr. 1. Uplatnění foresightu v cyklu tvorby politik. Zdroj: (Pazour et al., 2017)

\footnotetext{
${ }^{8}$ Megatrendy jsou navzájem závislé sociální, ekonomické, politické, environmentální a/nebo technologické změny, které patří mezi systémové charakteristické vlastnosti současných environmentálních výzev. Tento koncept znamená posun od zkoumání jednotlivých trendů k jejich komplexnímu hodnocení a predikcím, viz např. https://www.eea.europa.eu/soer\#tab-global-megatrends.
} 
budoucnosti a při jejich naplňování jsou pak potřebné kompetence související s kreativitou, inovativním myšlením, a dále akční kompetence. Simulovaný cyklus foresightu pak mưže tyto důležité aspekty rozhodovacích procesů (znalosti, kompetence) podpořit.

\section{Poděkování}

Článek vznikl za podpory Technologické agentury ČR, v rámci projektu TL02000012 „Udržitelný rozvoj na místní úrovni - propojení teorie a praxe" podpořeného ve výzvě 2 . veřejné soutěže programu na podporu aplikovaného společenskovědního a humanitního výzkumu, experimentálního vývoje a inovací ÉTA. Za cenné rady děkujeme Petru Čápovi, výkonnému řediteli Národní sítě místních akčních skupin.

\section{Literatura}

- Bagheri, A., Hjorth, P. (2007). Planning for sustainable development: a paradigm shift towards a process-based approach. Sustainable Development, 15(2), 83-96.

https://doi.org/10.1002/sd.310

- Cobb, P., Bowers, J. (1999). Cognitive and situated learning perspectives in theory and practice. Educational researcher, 28(2), 4. https://doi.org/10.3102\%2F0013189X028002004

- Council of Europe (1978). Permanent Education. Final report. Strasbourg,

- Dobeš M. (2019). Účast dospělých na vzdělávání v ČR byla v loňském roce 8.5\%. Dostupné z: https://epale.ec.europa.eu/cs/content/ucast-dospelych-na-vzdelavani-v-cr-byla-v-lonskem-roce-85

- Dvořáková, M. (2012). Teorie transformativního učení (se) dospělých. Studia paedagogica, 17(1), 59-74.

- Evropská komise (2019). Zpráva o České republice 2019. Dostupné z: https://ec.europa.eu/info/sites/info/files/file import/2019-european-semester-country-report-czech-republic_cs.pdf

- Evropská komise (2020). European Skills Agenda. Dostupné z: https://ec.europa.eu/social/main.jsp?catId $=1223$

- $\quad$ Faure, E.: Learning to be. Paris-London, Unesco-Harrap 1972.

- Kallen, D., Bergtsson, J.: Recurrent Education: a strategy for lifelong learning. Paris, OECD 1973.

- Kirova, M. P., Nedyalkov, A. N., \& Tsaneva, M. (2018). University as Prerequisite for Sustainable Regional Development in International Context. Economics, 10, 11th.

- Kearsley, G. (2010). Andragogy (M.Knowles). The theory Into practice database. Retrieved from http://tip.psychology.org

- Knowles, M. (1984). The Adult Learner: A Neglected Species (3rd Ed.). Houston, TX: Gulf Publishing.

- Knowles, M. (1984). Andragogy in Action. San Francisco: Jossey-Bass.

- Lansu, A., Boon, J., Sloep, P. B., \& van Dam-Mieras, R. (2012). Changing professional demands in sustainable regional development: A curriculum design process to meet 
transboundary competence. Journal of Cleaner Production.

https://doi.org/10.1016/j.jclepro.2012.10.019

- Memorandum on Lifelong Learning: Commission Staff Working Paper (October 2000) - dostupné na webových stránkách EU: http://ec.europa.eu/education/policies/III/III en.html

- Meyer, J., Pillei, M., Zimmermann, F., \& Stöglehner, G. (2018). Customized Education as a Framework for Strengthening Collaboration between Higher Education Institutions and Regional Actors in Sustainable Development-Lessons from Albania and Kosovo. Sustainability, 10(11), 3941. https://doi.org/10.3390/su10113941

- Mezirow, J. (1991). Transformative dimensions of adult learning. ERIC.

- Mezirow, J. (2006). An overview of transformative learning. In P. Sutherland \& J. Crowther (Eds.), Lifelong learning: Concepts and contexts (pp. 24-38). New York: Routledge

- MŠMT (2007). Strategie celoživotního učení ČR. Ministerstvo školství, mládeže a tělovýchovy, Praha 2007. Online dostupné https://www.msmt.cz/vzdelavani/dalsi-vzdelavani/strategie-celozivotniho-uceni-cr.

- MŠMT (2014). Strategie vzdělávací politiky České republiky do roku 2020. Ministerstvo školství, mládeže a tělovýchovy. Online dostupné na https://www.msmt.cz/uploads/Strategie_2020_web.pdf. ISBN 978-80-254-2218-2

- MŠMT (2019). Hlavní směry vzdělávací politiky 2030+. Dostupné z: https://www.msmt.cz/file/51582/

- MŠMT (2020). Strategie vzdělávací politiky České republiky do roku 2030+. Ministerstvo školství, mládeže a tělovýchovy ČR. ISBN 978-80-87601-47-1. Online dostupné na https://www.msmt.cz/uploads/Brozura S2030 online CZ.pdf

- MPSV (2017). Práce 4.0. Zdroj: https://www.mpsv.cz/web/cz/prace-4.0

- Palán, Z. (2006). Celoživotní učení. In Kalous, J., Veselý, A. Vybrané problémy vzdělávací politiky. Praha: Karolinum.

- Pazour, M., Pokorný, O., Valenta, O. (2017) Foresight - efektivní nástroj veřejné správy. TC AV ČR, online https://www.tc.cz/cs/publikace/publikace/seznam-publikaci/foresightefektivni-nastroj-verejne-spravy

- Smith, G. A., \& Sobel, D. (2014). Place-and community-based education in schools. New York: Routledge.

- Sol, J., Beers, P. J., Wals, A. E. (2013). Social learning in regional innovation networks: trust, commitment and reframing as emergent properties of interaction. Journal of Cleaner Production, 49, 35-43, https://doi.org/10.1016/j.jclepro.2012.07.041

- Stejskalová, Rozálie (2021). Místně zakotvené učení [online]. Enviwiki,[citováno 24. 11.. 2021 ]. On-line: < https://www.enviwiki.cz/w/index.php?title=M\%C3\%ADstn\%C4\%9B zakotven\%C3\%A9 u\%C4\%8Den\%C3\%AD\&oldid=25521 >

- UNECE. (2016). Learning from each other: achievements, challenges and ways forward. Third evaluation report of the UNECE Strategy for Education for Sustainable Development (Roč. 2016). Online https://www.unece.org/fileadmin/DAM/env/esd/11thMeetSC/Documents/1521609E.pdf

- UNESCO. (2017). Education for Sustainable Development Goals Learning Objectives. UNESCO. http://unesdoc.unesco.org/images/0024/002474/247444e.pdf 
- Van Merriënboer, J. J., Kirschner, P. A., Paas, F., Sloep, P. B., \& Caniëls, M. C. (2009). Towards an integrated approach for research on lifelong learning. Educational Technology, 3-14.

- Wals, A. E. (2007). Social learning towards a sustainable world: Principles, perspectives, and praxis. Wageningen Academic Pub.

\section{Dřívější práce autorů, zaměřené na vytváření zdrojů pro udržitelný roz- voj regionů:}

- Barton, A., Dlouhá, J., eds. (2014). Exploring regional sustainable development issues. Using the case study approach in higher education. Grosvenor House Publishing LTD., UK, online: https://www.czp.cuni.cz/knihovna/SD Case Studies.pdf

- Dlouhá J. (2014). Sustainable development case studies and their use as a teaching method in regionally focused higher education programs. In: Barton, A., Dlouhá, J., eds. (2014). Exploring regional sustainable development issues. Using the case study approach in higher education. Grosvenor House Publishing LTD., UK

- Dlouhá, J., Barton, A., Janoušková, S., Dlouhý, J. (2013). Social learning indicators in sustainability-oriented regional learning networks. Journal of Cleaner Production, 49, 6473. DOI: $\underline{10.1016 / j . j c l e p r o .2012 .07 .023}$

- Dlouhá, J., Dlouhý, J., Kapitulčinová, D. (2016). Metodika tvorby a využití př́padových studií ve výuce a formou Open Educational Resources (OER). Envigogika, 11(1). Certifikovaná metodika, DOI: $10.14712 / 18023061.515$

- Dlouhá, J., Heras, R., Mulà, I., Salgado, F. P., Henderson, L. (2019). Competences to Address SDGs in Higher Education-A Reflection on the Equilibrium between Systemic and Personal Approaches to Achieve Transformative Action. Sustainability, 11(13), 3664.

- Dlouhá, J. (2015) Regional Knowledge for Competence Based Teaching: Transformative Processes in the Czech Education Context. In: Fleischmann, O. et al. (eds) The Teaching Profession. Zurich: LIT Verlag GmbH \& Co. KG Wien, pp. 48-56. ISBN 978-3-643-90 681-6

- Dlouhá, J., Zahradník, M. (2015). Potential for social learning in sustainable regional development: analysis of stakeholder interaction with a focus on the role of scientists (Potenciál pro sociální učení v regionálním udržitelném rozvoji: analýza interakcí aktérů s důrazem na roli vědců). Envigogika, 10(1). ISSN 1802-3061.

DOI: http://dx.doi.org/10.14712/18023061.476 Dostupné z http://envigogika.cuni.cz/index.php/Envigogika/article/view/476

- Kauzy udržitelného rozvoje: http://enviwiki.cz/wiki/Kategorie:P\%C5\%99\%C3\%ADpady kauz udr\%C5\%BEiteln\%C3\%A9ho rozvoje

- Př́padové studie udržitelného podnikání na venkově: http://enviwiki.cz/wiki/Kategorie:Udr\%C5\%BEiteln\%C3\%A9 podnik\%C3\%A1n\%C3\%AD - p\%C5\%99\%C3\%ADklady firem

- Portál Udržitelný rozvoj na místní úrovni: https://enviwiki.cz/wiki/Port\%C3\%A1l:Udr\%C5\%BEiteln\%C3\%BD rozvoj na m\%C3\%ADstn\%C3\%AD \%C3\%BArovni 